\title{
RELEVANCE OF THEOLOGY IN RELATION TO SPIRITUALITY: AN AFRICAN BANTU PERSPECTIVE
}

\author{
Francisca Chimhanda \\ Philosophy, Practical Theology and Systematic Theology \\ University of South Africa
}

\begin{abstract}
This article explores the mutual influencing of theology and spirituality in a quest to make theology relevant and coherent to the community of faith it serves. In this case, special focus is on African Christians in their cultural, political, economic, and historical situatedness. Acknowledging that African culture is diverse, special attention will be given to Bantu African culture with the spirituality undergirded by Ubuntu values. Important issues to be pursued include the quest for identity, self-actualisation and destiny in the God-humancosmos mutual connectedness. Important to note is the missionary endeavour to inculturation and its mutual influencing with the Incarnation and evangelisation in the sense of enfleshing the Gospel message in time and space. Culture is seen here as antecedent to evangelisation as concerns the spiritual, pedagogical and comparative elements of theological discourse. Another important factor to note is the African holistic religious worldview that sets religion and theology as inextricably bound up with all of life. The article will follow a multi-disciplinary approach that culminates in advocacy for a theology sensitive to the signs of the times.
\end{abstract}

Key Words: African; Aggiornamento; Bantu Perspective; Holistic Worldview; Communal Ontology; Epistemology; Inculturation; Incarnation; Theology; Spirituality; Theanthropocosmic

\section{Introduction}

This article explores the mutual relationship of African Bantu theology and spirituality in the God-human-cosmos interrelatedness and, with special reference to Shona Christians of Zimbabwe. This is done in the context of a Bantu holistic worldview undergirded by communal ontology and epistemology and in the light of Christian theology and spirituality. It is noteworthy to mention that the Shona ethnic group is a sub-group of Bantu. In this creative dialogue of culture and the gospel, this is an attempt to show how theology and spirituality impact on people's lives in the quest for identity, meaning of life, human destiny and in addressing socio-economic and political issues in maintaining quality of life. Similarly, there is an attempt to show how African Bantu theology and spirituality contribute to the universal church and society today. Theological loci include quintessential doctrines of God, Christology, pneumatology, ecclesiology, and eschatology. Technical terms, i.e. culture, religion, faith, and spirituality, inculturation, Incarnation and evangelisation are explained. 


\section{Religion}

Religion stems from faith in a Supreme Being - the 'Ultimate Other' (Tillich 1968, I:14-15, 234-245), or 'Mystery' (Rahner 1996:22). As such, it is a way of life or worldview in which people live out their relationship with the Supreme Being and other created reality. In this context, Kaufman (1972:29-31) explains that religion develops in order to give a coherent interpretation to life that will sustain the social and personal order within which people of a given society are living when they pass through such experiences as death, suffering and calamity. Consequently, through religious beliefs and experiences people are able to cope with crises of life, that is, by relating them to positive experiences of meaning and value. According to Ayisi (1972:1-2 - see also Chimhanda 2011:122-126), culture is a complex whole that includes religious, socioeconomic and political elements. We can thus say that people of every culture and religion have an orientation towards God (Supreme Being or Ultimate Reality) in the God-human-cosmos interrelatedness and interconnectedness.

\section{Spirituality}

Spirituality may be understood as the inner dynamism that shapes people's lives especially in the innate quest for self-understanding, self-expression, identity and fulfilment in relation to God. According to Rahner (1987:34), human beings as spirit are able to transcend their finitude or limitations in attaining knowledge of God. He explains that in this way human beings have an innate and infinite capacity for divine epistemology. Rahner says humans have a infinite horizon of experience of the Transcendent God. In other words, in the historical development of divine revelation, new horizons are continually unfolding.

\section{Theology}

The classical definition of Christian theology as 'faith seeking understanding' - fides quaerens intellectum (cf. St Anselm of Canterbury 1033-1109) - sets theology in service of faith and spirituality. In the context of inculturation, understood as a creative dialogue of culture and the gospel, theology helps us to identify, elaborate and appropriate time-honoured cultural and gospel values in the process of what Pato (1989:53-61) called being 'fully human' (as undergirded by Ubuntu values). For example, Shona Ubuntu values include unhu, (personhood), umwe (togetherness), ushamwari (friendship), and kugamuchira vayeni (hospitality).

\section{Inculturation}

Inculturation is a process that gives content to the Incarnation as a lived reality in a particular culture and time. According to Sheldrake (2000:63), in the Incarnation, God showed commitment in Jesus Christ to a world of place and time. In other words, God became human in the person of the historical Jesus of Nazareth. In the person and work of Jesus there is the twofold movement of 'God becoming human' and humanity being invited to become like God (divinisation) (Lane 1992:11). In this sense, inculturation is synonymous with the incarnation in which it is found that God exceeds particularities of every culture in making the Incarnation a lived reality for humankind. In pedagogical (teaching and learning), comparative (cultural elements are examined in the light of 
gospel values) and spiritual (appropriation of spiritual values ) approaches, it is acknowledged that the people of a particular culture are not a tabula rasa concerning orientation towards and knowledge of God. In other words, it can be said that God/Christ was not a stranger among African Bantu Shona people prior to Christian evangelisation. Kofi Asare Opoku (in a keynote address to $2^{\text {nd }}$ Colloquium Conference of the University of South Africa, the Institute for Diasporan and African Culture and Drew University, 3-5 October, 2012), accentuates this view in claiming that when the missionaries came, the Africans already knew and served God. Thus, St Paul in Athens at the Areopagus demonstrated the pragmatism of proceeding 'from the known to the unknown' in pedagogy (Acts 17:22-31). Nyamiti (1973:18) accentuates this point in asserting that culture is a praeparatio evangelica (a precedent to Christian evangelisation).

It is important to note that in the process of inculturation, culture and the Bible each has dual nature. This is because they always seem to be "dynamic and accommodating, liberating and oppressing, socializing and alienating, useful and irrelevant" (Punt 1999:313). Kanyoro (2002:13) accentuates this point as follows:

In some instances culture is like a creed for the community identity. In some

instances culture is the main justification for difference, oppression and injustices'.

Nyamiti (1973:19) concurs with this view in explaining that inculturation is a process of rejection, correction, completion and refinement of cultural elements in the light of the gospel.

Inculturation has two other distinct and mutually influencing processes - 'enculturation' (learning from one's culture) and 'acculturation' (learning from other cultures) (Luzbetak 1988:65-66). In the context of globalisation, we acknowledge that there is no pure culture. Rather, there is a confluence of cultures. Wilfred Cantwell Smith accentuates this point in saying that Christianity itself consists of a plurality of cultures (cf. Hick 1973:124). Culture then is not static, but is constantly evolving in an on-going process of learning and adapting to new situations of confronting norms and forms of life (Pobee 1992:34-35).

Pobee (1992:39) proposes a movement from kenosis (self-emptying) to skenosis, where the root word skenoo denotes a tent or an abode (pitching the tent or the tabernacling of the soul of the eternal and non-negotiable Gospel of Christ). Christian values that are non-negotiable reside in the Christ-event (the life, work, death and resurrection). Inculturation, as a creative dialogue of essential cultural elements (e.g. Ubuntu, 'personhood' values), with the saving act of God in Christ, is aimed at making believers feel at home in their own faith and culture. In the context of Christian faith in dialogue with socio-economic, politically and technologically changing society, Pope John XXIII (1963) proposed the process of aggiornamento (Italian: updating) for a theology sensitive to the signs of the times (Pobee 1992:35).

\section{Christian Spirituality}

Christians believe in one God in three persons of Father, Son and Holy Spirit. According to Gaybba 1987:3), the English word 'spirit', is derived from the Latin word spiritus (breath or breathing). This has equivalents in the Hebrew ruach and Greek pneuma (wind, air, steam or air). In the Bible, then, spirit is used as dynamic creative breath of God (Gen. 1:2), or powerful wind (Gen. 8:1; 1 Kings 19:11). In the biblical 
wisdom literature (Proverbs, Job, Ecclesiastes), 'wisdom' (Greek: Sophia; Hebrew: Hokmah) is personified (as female) as active in creation and fashioning the world in her imprint (Prov. 1:20-23; 9:1-6; Job 28: Eccl. 24) (McGrath 1997:293). In the New Testament the Holy Spirit is understood as the third person of the Trinity and also in dynamic terms as the unifying and communication factor in the life of faith and growth of the church (Mt. 28:19; 2 Cor. 13:14). Christian baptism is by water and the Spirit and in the baptismal indicative and imperative the Spirit is understood as the seal (guarantee) of believers, who are called to walk in the Spirit; the Spirit intercedes for us with sighs too deep for words (Rm. 8:22-27); believers are said to be endowed with spiritual gifts (1 Cor. 12:1-31; Eph. 4:7-13). In conclusion, it can be said that spirituality is the driving force which animates life-giving actions and experiences love, forgiveness, peace and joy, in relation to God.

In Christian theology, humankind as spirit is said to be transcendent - to transcend human limitations in the quest for God. Rahner (1987:37) claims that in this orientation, humans have an infinite capacity to ascend to knowledge of God, through an infinite horizon of experience. This aspect is explored in terms of Bantu (Shona ethnic group) essential cultural elements of vital energy and participation in an ethic that flows from ontology in the light of the Christian doctrine of perichoresis - the mutual influencing of the Trinitarian persons of the Godhead - the belief in the mutual interpenetration cooperation of the Godhead in opera ad intra (internal work) and opera ad extra (external work) in the Trinitarian koinonia (fellowship) and the economy of salvation, respectively.

\section{African Bantu Spirituality}

Generally, African Bantu people are very religious. In this context, Pobee (1992:69) asserts that Homo Africanus experiences the mysterium tremendum in community. The African Bantu (Shona) holistic religious worldview and therefore, spirituality, admits to a close union and mutual influencing of the mundane and extra-mundane worlds (Mulago 1991:119-120). Archbishop Emeritus Desmond Tutu (1995:xvi) aptly explains:

The African worldview rejects popular dichotomies between the sacred and the secular, the material and the spiritual. All life is religious, all life is sacred, all of life is of a piece.

Pato (1997:55) accentuates this view in saying "the whole rhythm of daily life is a continuous liturgy that permeates such commonplace things as eating, drinking, ploughing, working etc.” In this vein, Reverend EK Mosothoane (cf. Kuckertz 1981:12, 80) came up with the concept of the African communio sanctorum.

But African culture is a complex whole and it is acknowledged that there are commonalities and differences among African people and their respective cultures. To the question whether it is possible to speak from a perspective of African culture and spirituality when the continent is so vast and consists of a pluriform of cultures, Pato (1997:54) answers to the affirmative. He explains that: 
There is an astonishing congruity in African cultures and religion when one considers the substratum values and attitudes... The variation in religion has less to do with the ideas themselves than with their expression by means of dissimilar elements linked to occupations and the flora and fauna of the area.

However, to avoid oversimplification, African theology and spirituality of the Bantu will be explored with concrete examples drawn from the Shona people of Zimbabwe as a Bantu sub-group.

The Bantu believe in unity of the physical and the spiritual, the visible and invisible worlds. There is belief in the Supreme Being who is spirit and mystery. Shona Bantu Christians in dialogue with traditional religion have named God Mwari. But the Shona have no coherent Mwari myth. The etymology of Mwari, the Supreme Being and Creator of all things is from muhari (in the pot) or Maari (in Him/Her) or Muari indicating the enigmatic character of Mwari and this is in parallel with the character of Yahweh, the God of Israel described as I am who I am (cf. Ex. 3:14).

Designations of Mwari as Creator par excellence - Pantokrator (one who holds all created reality in being) include: Musikavanhu (Creator of human beings), Musiki (Creator of all things), Nyadenga (Lord of the skies), Chidzachepo (Eternal Being); Zendere (mythical young woman regarded as Mwari's emanation) (Daneel 1970:16), Dzivaguru (Greatest Pool); Sororezhou (Elephant's head) etc. Whereas Nyadenga and Sororezhou affirm male headship, Zendere and Dzivaguru affirm female reproductive potency (Chimhanda 2011a:82). Moreover, Shona language is gender neutral and spiritual leaders include both men and women.

The Mwari cult is traced from agrarian people of Tanzania in the lake region in the vicinity of Mt Kilimanjaro (Daneel 1970:24). In the historical Bantu movement from Central and East Africa, the Shona are said to have migrated from this region to the south. In this perspective, Mwari, the God of the Shona communio sanctorum is worshipped as a universal God who gives rain and sunshine to all and is thus responsible for the fertility of both humans and the land. In this perspective, everything has sacramental value. Thus majiri (indigenous forest reserves) anoyera (are holy) and give wild fruits, mushrooms, honey, etc. in due season and these are meant to be available to all people and other created reality. On the same note, these gifts from Mwari are supposed to be collected with reverence and sparingly. Violation of the rules of the forest can result in punishment from Mwari through the ancestors (Chimhanda 2011b:70). Mwari understood this way is not a Deus otiosus (remote God disinterested in human affairs), but a dynamic presence accessible through the ancestral mediation ladder.

Relational attributes that point to the dynamic presence of God abound in Shona theophoric names. These include Tinashe (God is with us - a Shona equivalent of Emmanuel [Mt 1:21]); Simbarashe (power/strength of God), Kudakwashe (will of God), Ruvarashe (flower of God), Ngonidzashe (mercy of God), etc. The suffix -she here stands for ishe (chief or king).

There are also names of how the Shona experience and show what God is doing in their midst. These include: Munyaradzi (Comforter), Tadiwanashe (we have been loved by God), Tawonanyasha (we have seen or experienced God's mercy), Tafadzwa (we have received joy), Tapiwa (we have been given), Tawananyasha (we have received mercy). Other names show reciprocal response to God's blessings - Tatenda (we thank), Tendai (thank), Rumbidzai (praise), Ruramai (be upright), Mukai (arise), etc. 
Mulago (1991:119) highlights the following four essential characteristics of Bantu communion sanctorum:

1. Unity of life and participation,

2. Belief in the enhancement or diminution of beings and the interaction of beings,

3. Symbols as the principal means of contact and union,

4. An ethic that flows from ontology.

In this context, Charles Nyamiti (1973:12) asserts that:

Grace is communal ... ecclesial ... ancestral and as such Christian ... paradisiacal ...

heroic ... friendship, initiatic and therefore, sacramental, Pentecostal, Eucharistic,

living dynamism, fecundity, eschatological...

The Roman Catholic Church African Synod of Bishops (Rome 1994) concurred with this view in its postulate of the model of the Church in Africa as family. As such, the church as family is modelled on the Trinitarian koinonia (togetherness) undergirded by the doctrine of perichoresis (mutual interpenetration of the three persons in the Godhead) particularly in the economy of salvation.

According to Charles Wanamaker (1997:286-293), Bantu ancestors are assigned three primary roles as:

1. Givers and sustainers of life,

2. Guardians of the social and moral order,

3. Mediators.

Ancestors are acknowledged as the living dead who in dying have spiritual power from Mwari and participate in the lives of their living descendants. On petitioning for anything, the Shona always evoke God and the ancestors. For example, they understand that children are a gift from God through the ancestors. In the Shona religious worldview, we can distinguish two kinds of ancestors - vadzimu (family spirits) and mhondoro (lion spirits). The latter are then understood as the highest primogenitor at the apex of the ancestral ladder. Lion spirits are also called makombwe (singular: Gombwe). These are the highest primogenitures on the chiefly dynasty. Land acquisition and settlement in different areas of Zimbabwe is associated with the specific area mhondoro who are thus acknowledged as owners of the land. The Shona therefore observe rules of the land which include reserving a specific day of the week as chisi (rest day similar to the Christian Sabbath). For example chisi day in Serima (my home area) is Thursday. Consequently Shona people (including Christians) in rural Zimbabwe keep two Sabbath days per week. It is in this context that Schoffeleers (1978:235-313) calls the mhondoro 'guardians of the land' or tribal tutelary spirits.

According to Bourdillon (1976:294-317), the greatest gombwe of the Karanga and Zezuru is Chaminuka as subscribing to the Mwari cult. Schoffeleers (1978:235-338) and Bourdillon give Mutota as the greatest gombwe alongside Dzivaguru and Karuva among the Korekore. According to Bourdillon, Karuva is the highest gombwe among the Manyika, and on par with Chaminuka. Paul Gundani (personal communication), gives area makombwe - Rasa for the Karanga (Gutu area), Chaminuka, for the Zezuru (Epworth, Chitungwiza area).

Mhondoro living hosts are called mhondoro masvikiro (lion spirits mediators). Interviewees (VaViolet, late Chief Serima and VaNyakurwa) acknowledge both men and women mhondoro masvikiro they have known and encountered in their times. 
Interviewees explain that the main function of the mhondoro is mediation in calamities e.g. pestilence (from locusts, army worms - devastating crops), illness, drought, war. VaViolet explained that in some cases the mhondoro masvikiro may foresee such calamities and advocate remedies. Both chief Serima and VaViolet talked about the importance of nhendo (thanksgiving) particularly for a good harvest. They noted that whereas today this tends to be omitted, traditionally, people had to wait for the nhendo ritual in order to pick fresh crops or vegetables (such as the traditional vegetable muboora, 'pumpkin leaves') from the fields (Chimhanda 2011a:68-69). In the latter context, nhendo is also called kuruma gore (a 'bite' or 'taste' of first and new produce of the 'year' - Paul Gundani, personal communication).

\section{Communal Epistemology}

The Shona proverb Panorairwa mwana washe muranda teerera (a servant should listen attentively when a chief's child is given advice) lays emphasis on communal epistemology. In everyday parlance, the emphasis is on learning from others despite age, class, ethnical and creedal differences.

\section{An Ethic that flows from Ontology}

Bantu cultural values are enshrined in the ethic that flows from the ontology, i.e. identified as cognatus ergo sum (I am related, therefore we are) (John Mbiti 1969:108,109; John Pobee 1992:66). Thus African Bantu religion and spirituality are lived in a network of relationships undergirded by four specific ethical values, unhu (personhood), umwe (togetherness), ushamwari (friendship), kugamuchira vayeni (hospitality).

\section{Unhu (Personhood)}

According to Pato (1997:55-56) in the African holistic worldview, a person is never born whole and attains the fullness of life or full humanity through participation in a series of rites de passage that take place from before birth to life after death. The family, clan and tribe to which one belongs enable one to become a mature human being. Thus the Shona munhu chaiye (real person) is respectful of elders, considerate of the needs of others and "adheres to time-honoured ritual observances which bind together all members of the group, both living and dead" (Shirley Thorpe 1991:53). When the individual deviates from the standard behavioural expectations, the Shona say to such a person, hauzi munhu (you are not a person), or, hauna hunhu (you have no personhood). In a scolding or derogatory way, they say, urimbwa yemunhu (you are a dog-like person) (Chimhanda 2011:132). Corporate personality among the Shona is undergirded by totemism.

\section{Totemism}

Shona totemism creates a universe nostalgic a paradise - a place where humans, animals and other created reality are ontologically intertwined harmoniously. The totem is very important in that it links one to the primogeniture and gives a person corporate identity. On one hand, totem praise names (Shona: chidavo) affirm good characteristics (strength, power, headship e.g. for the lion and elephant totems) and bad elements 
(stealing, cunningness, tendency to have white hair on ageing for the monkey totem) of the animal in question. On the other hand, the praise names are anthropomorphic and have subtle sexual connotations since the full praise names are used in the rhythm of the conjugal act. More important still, the totem and praise names are recited in the funeral rite and this is a prerogative for correct burial. In this context, the Shona show a kind of xenophobia. They are afraid to harbour a total stranger because they are afraid to be implicated in ngozi (vengeance spirits) for not giving the stranger a correct burial. Otherwise the totem and the first line of praise names are used in everyday greeting and especially when thanking. The underlying principle is that a person has group value. Thus in the totem symbolism, it is the person's whole family, clan and the living dead ancestors who are greeted and thanked. Although Shona totems are acquired through patriarchal lineage, in everyday parlance, the Shona say mai mudzimu wangu (mother is my ancestor).

There are also taboos linked to the totem. These include abstaining from eating the animal or the part of the carcass that is one's totem and this is linked to the incest taboo - marriage within one's totem is forbidden. It is important to note that the latter practice is affirmed by modern science as good in widening the gene pool and thus in preventing abnormalities that may occur through in-breeding.

\section{Shona Ethic of Umwe (Togetherness)}

The factor of togetherness is highlighted in the Shona traditional practice of humwe (people gather for a common task such as ploughing, weeding, harvesting, threshing and winnowing of grain where the host provides a festal meal and home-brewed beer). There are several Shona proverbs that lay emphasis on umwe. These include:

1. Gunwe rimwe hari tswanyi nda (One thumb cannot crush a louse) and

2. Rume rimwe hari kombi churu (One big man cannot circumvent an anthill).

There are many rhythms that emanate from people working together on land, especially in initiating rhythmic threshing of grain. These in turn have enriched Shona Christian liturgy - it is no wonder that the Church in Africa is acknowledged as the dancing church.

\section{Bantu Value of Ushamwari (Friendship)}

The Shona say ushamwari hunokunda ukama (friendship has greater value than consanguine relationship. Indeed, for the Zezuru sahwira (friend) is not necessarily a blood relation and plays a significant role especially at funerals - a role equivalent to the Karanga muzukuru (niece or nephew). The Karanga also say muzukuru anokunda mwana wokubereka (a grandchild is greater than one's own child).

The Shona put a high stake on hospitality. This is evidenced in their having a time of day called ruvhunzavayeni (time of dusk when visitors are expected to arrive and - if strangers - ask to be put up for the night). There is also the idiom zhara shura mweni (hunger is a good omen for a coming visitor and thus a festal meal). The Shona allow the visitor to upset their budget in providing a festal meal.

The stranger is directed to the village headman or chief. The chief also provides for the needy - in line with the biblical anawim (poor of Yahweh) trio of widow, stranger and orphan (Ex. 22:21-24; 23:9; Leviticus 19:33-34; Deut. 27:19; 24:17). The Shona 
enable the chief to do this through the practice of zunde ramambo (the people work in the chief's field and the proceeds are used for the needy).

The Shona also see physically and mentally challenged people as vanhu vaMwari (people of God) in line with the biblical anawim. These are to be meticulously cared for according to the biblical view that some people entertained God in the guise of a stranger without knowing it. With this in mind, I will proceed to explore the ontological significance of land, land as ancestors, humanity's role of steward and lord over creation, ecofeminism and eco-justice, and future prospects of a theology of land.

Again, traditionally there were crops considered zvinhu zvinodyiwa nevapfuuri (things to be eaten by hungry passers-by or travellers). There are proverbs that lay emphasis of Shona generosity. These include:

1. Kupa kukanda tsapo mhiri kwerwizi (to give is to throw one's baggage across the river).

2. N'ombe yokuronzwa haipedzi uswa (Cattle entrusted to a person does not deplete the grass) (Chimhanda 2011b:133-134).

\section{Belief in the Enhancement of Diminution of Beings and the Interaction of Beings}

In Shona communal ontology and epistemology, the individual can affirm life or be lifethreatening when showing responsible behaviour or engaging in anti-social acts, respectively. This aspect is demonstrated in the Shona understanding of extended patients (Chavhunduka 1977:142-143).

\section{Shona Holistic Healing}

The Shona subscribe to holistic healing in which God, ancestors and n'angas (traditional healers) are the key players. Healing from physical and psychosomatic illnesses is very important because of the Shona's chronic fear of witches and sorcery. God is the ultimate healer who heals without medicine. Ancestors too are understood to heal without medicine, because in dying they have come close to God and have gained spiritual powers. Alternatively ancestors are believed to bestow healing knowledge and power on their living host. God in Christ was committed to restoring wholeness to people suffering from various ailments - physical and psychosomatic disorders.

Concerning psychosomatic therapy implicated in the concept of extended patients, the Shona show collective conscience and corporate identity as regards anti-social acts and the responsibility that goes with that. In the example of the case of murder mentioned above, the Shona believe that vengeance spirits will wipe out the whole family and clan and the offender is the last person to be affected. They therefore say mushonga wengosi kuripa (the best panacea against ngozi is propitiation). However, there is one sin that echoes the biblical sin against the Holy Spirit for which the individual must take full responsibility, that is, the sin against the mother.

The Shona believe that the individual who engages in physical or psychological violence against the mother has to make reparation while the mother is alive. If that is not done, when the mother dies, the offender will suffer psychosomatic illness in the process of kutanda botso. Here the individual wears sackcloth and goes from house to house, and village to village begging. The agnates have to intervene in making 
reparation to the deceased mother's natal group after which the offender regains normality.

\section{Symbols as the Principal Means of Contact and Union}

In the mutual connectedness of land and humans, the Shona believe that land is the ancestors and that as such, they are 'children of the soil' (vana vevhu). Traditional holistic healing affirms spiritual power through hierophantic contact with the invisible world by using objects e.g. water, tsvimbo (ancestral staff), salt, oil and snuff. Here there is a striking parallel with Christian use of holy water, oil and salt, prophesying and divination (Mulago 1991:124-124; Daneel 1970:33; Mavi 1985:10-25; Chimhanda 2011a:146) especially as practised by African Initiated Churches.

Shona healing practices show mutual interdependence with the environment in that medicines such as herbs, tree bark and roots must be collected in such a way as to allow availability to many others and in particular growth and propagation. The emphasis is on good stewardship. Here the Shona have a proverb - kunzi opakata hakuzi kuti ridza (when you are asked to hold an instrument, this does not mean that you should play it). Practical examples exist of acknowledging the ultimate giver and of conservation in collecting herbs. There is ritual kneeling and clapping to thank God and the ancestors before one collects and leaves part of the plant to allow for continued growth. On picking tree bark, one must take a little from Kumabva zuva (direction sunrise - the east) and madokero (direction sunset - the west). This is not only to ensure the tree does not die, but also the Shona understand that as the tree heals, one is also healed of whatever ailment (Paul Gundani - personal communication).

Another striking example of eco-userfriendly practice is found in Shona traditional burial. On top of the grave, the Shona plant the shrub chizhuzhu, aptly also called muvigavafi (that which buries the dead). This is a type of resurrection plant. The Shona find that the shrub is medicinal for a number of ailments.

\section{Soil}

The hermeneutic key to understanding the link between ancestors and land is found in Shona symbols of life that include totemism, soil, blood, womb and water (Aschwanden 1982:23; Chimhanda 2011a:85; Manley 1995:70-74). Thus, in a culture-Christianity dialectic, it can be said that for the Shona land is familial, communal, sacramental, liturgical, life-giving, healing and eschatological.

Marcelle Manley (1995:70-75; see also Chimhanda 2011a:91-93) explains that among the Shona, vhu (soil) is not just the material base of the subsistence economy of people, but represents the very power of chieftaincy. In the soil symbolism, and Shona understanding of ancestors as guardians of the land, the chief as an amanuensis is a power to reckon with. Unlike modern political functionaries, the chief has spiritual powers vested in him/her by the soil through the mhondoro masvikiro. Consequently, the soil is both the founding ancestors who conquered it and the rulers by which those who occupy the land today - vatorwa (aliens) and living descendants have to obey. Manley $(1995: 72,74)$ emphasizes this view as follows: 
Morals governing life are issued by the soil and breaches of these rules incur not only material penalties, but in extreme cases, also drought, disease, sterility and death. This is the very ground of chiefly authority even in these times of rapid change.

Territorial integrity is maintained in that ancestral land is where one is buried. Most Shona in urban areas maintain rural ties - they come from towns and the Diaspora to be buried in rural homes. When entering alien territory, the Shona have the ritual of kunanzva vhu (lick the soil) so as to redeem oneself from alien spirits. And again, if one dies and is buried in alien territory, the Shona have the ritual of kutora mudzimu. They take soil from the grave for ritual burial of the deceased kin in ancestral land. The ritual of kutora vhu (mudzimu) applies when one moves place to settle somewhere, that is, soil is taken from ancestral graves (Chimhanda 2011a:92-93).

\section{Womb}

It is also important to note the link between the grave as the earth's uterus and the mother's womb. As mother and the great womb, land is the eternal home in that the grave is understood as imba (house) which everyone helps to construct, even by merely throwing soil onto the coffin. Indeed, early in the morning after burial, the Shona perform the ritual of kumutsa (awaking the deceased - asking for well-being in the new home). The ritual is still performed today but Christians now include prayer to God/Christ for the deceased.

The Shona refer to the dead as vari pasi (those from below). Consequently, when making petitions to the dead (on going on a journey, illness, etc.), there is the ritual of kukanda fodya pasi (to throw snuff on the ground). Pertinent to affirming the dignity of women in Shona spirituality, it is important to note that the family prayer place is woman space, the kitchen huva (shelf mounded from soil) where clay pots and other kitchen utensils are stored. Moreover, the mother's round hut with a central fire (cooking place) is a space for recreation and also a place where the body lies in state, especially for the night stay (vigil).

Although Shona patriarchal marginalization negates women as vatorwa (alien) and tends to treat them like a field receptive to male seed, the crucial and active role of women in human reproduction is affirmed in Shona proverbs, songs and pithy sayings. Taking the concepts of birthing and parenting, that run parallel to the understanding that from the produce of the land we are nourished, secured and healed, Shona proverbs hail the mother as follows: zamu guru ndera mai (mother has the bigger breast [to feed to satiety]); kusina mai hakuyendwi (you do not go to a place where your mother does not dwell, that is, home is where the mother is; baba ndi mupakamwe (father gives once), mai ndi mupa kaviri (mother gives twice). It is important to note here that modern science has thrown light on this, in particular, the science of genetics and sex determination.

There are Shona sayings that show that maternal consanguine relations are stronger than patriarchal ties. Here reference is to the importance of the dumbu (womb). The Shona say: uyu mwana wamai vangu (this is my mother's child), mukoma, munin'ina, hazvanzi yangu womudumbu rimwe - buda ndibudewo (my elder, younger, sister/brother from the same womb - come out so that I may follow). Also when it comes to life-threatening momentary experiences, the Shona always ejaculate mai-we! 
Connected to the womb is the mbereko (back sling) symbolism. The root word of mbereko is from kubereka (to carry or give birth), and hence the reference to chibereko (the womb).

The Shona attribute womb qualities to the protective work of maternal ancestors. In situations of illness or death, the Shona say, mudzimu wamai wadambura mbereko (maternal ancestors have broken the back sling). For this reason, traditionally, in cases of barrenness, child illness or death, it was the woman who was blamed. They say the barren woman haana mbereko (does not have a back sling). From the point of view of mbereko, we can understand that the Manyika refer to land as musana (back). It is also obvious that reference is to the mother's back (Nisbert Taringa, in personal communication).

The Shona acknowledge the importance of the mother's back in a series of rituals surrounding birthing and nurturing most of which are part of the roora (bride price). The rituals include mavhunwa (damages), masungiro (redeeming damage done in psychosomatic association to parents' backs when the daughter is first made pregnant), and mbwazukuru (goat used to redeem maternal ancestors (woman's paternal grandmother) for protecting the womb and grandchildren). VaNyakurwa explains that in the masungiro ritual, the billy goat and nanny goat are used to redeem the father and mother, respectively. The billy goat is termed the chidyamushonga (that which is used in medication) since it is killed and eaten with medicinal herbs. But the nanny goat is left to produce the young.

The largest part of roora - the danga - is paid only when there are children born to the couple and this is done "to transfer the status of the child as a member of the maternal group to that of the paternal group. Consequently, Dora R Mbuwayesango (1997:27-28) makes a strong assertion that roora should more accurately be termed 'child price'. This is mainly at the disposal of the bride's father. Men therefore get the lion's share of roora.

However, as part of roora, the mother's role in birthing and parenting is also acknowledged in the payment of the mombe yehumai (mother's cow). Although other items of roora such as danga (a head of cattle) can be in cash and kind, the mombe yehumai must be 'on fours'. Its produce and that of the nanny goat form part of the mother's wealth.

\section{Water, Blood, Milk}

These body fluids are mutually connected biologically. In the Shona patriarchal worldview, children are a gift from God through the ancestors. In this case paternal ancestors use mutorwa wrapping (placenta) that prevents the foetus from coming into contact with the mother's (mutorwa) blood that is regarded as dangerous. At birth, the placenta and the umbilical cord are treated with reverence in the ritual of burial of the placenta. Hence, the importance of the Shona politically clamouring for ancestral land in which their placenta and umbilical cords are buried.

The Shona metaphor of the soil drinking blood of, for example, fallen heroes and heroines, or that of children who die prematurely, in turn, symbolizing angry ancestors and water, particularly flowing water is said to have donhodzo (cooling) and soothing effects. Women who die in pregnancy and after giving birth and children who die through miscarriages and infants who die before teething are referred to as vanhu 
vanyoro (tender and wet people). These people are buried in wet soil and children in particular are buried on river banks - alongside streams with flowing water (Chimhanda 2011a:93).

VaViolet and vaPriscilla (the prefix 'va' to an elderly person's name denotes reverence) maintain that the Shona's regard of the woman's blood as foreign does not make sense in view of the fact that during the nine months of gestation, the woman does not have menses. They explained that this points to the fact that the woman's blood is necessary for the health and growth of the foetus. They further vindicate maternal blood in that puerperal blood (that which flows for a few days after giving birth) is in symbolic circumcision of boys. Aschwanden (1982:37-38) hits the same note in saying that for the Shona puerperal blood is understood to be a mixture of both father's and mother's bloods which means that both worlds of vadzimu are represented in this blood.

In the interconnectedness of nature and humans, women in their menses are said to have hot blood so that when they come into contact with what is understood by the Shona as mainly women crops (peanuts, groundnuts), they say dzinotsva ('they burn' wither and die). If they insist on working the crops in this condition, they have to do kurapira (doctor them usually with the herb chifumuro [which acts as an antidote).

Besides the important role of breast milk in nourishing the baby, VaViolet explains that the Shona use milk of virgin girls to cure a number of child diseases (sore eyes, allergies etc.). Similarly, milk, understood by Shona to have mild and harmless effects, is used as prophylaxis when applied to genitals of both boys and girls (see also Aschwanden 1982:40-41) to calm and control their sexual drive.

\section{Shona Culture-Christian Dialectic}

A pertinent question to theological discourse of African religion and spirituality exists in whether it is possible to talk of ancestral religion and practices after centuries and decades of influence from interloping cultures through westernisation and Christian evangelisation. Michael Bourdillon, in his book, Where are the ancestors? (1993), answers to the affirmative. He confirms that from jettisoning traditional beliefs and practices, ancestral religion is very much alive among the Shona and many other African groups. Early missionaries negated African religion as subscribing to idolatry and fetishism but this resulted in superficial believers - Christians by daylight who backslide into cultural beliefs and practices in situations of illness and death.

A contested terrain is whether Africans worship ancestors or not - whether they are polytheists or monotheists. In some instances, e.g. the pouring of beer libation in the ritual of kurova guva (homing of the spirits), there is a thin film on whether it is ancestral worship or not. However, the above exposition shows that the Shona of Zimbabwe are monotheists. With Christian evangelisation, the Highest Being at the apex of the ancestral mediation ladder became more clearly defined as Mwari who defies full human comprehension. In this context, it is more appropriate to say that Africans did not convert from one form of theism to another. Rather, what has taken place among Shona Christians is a creative 'reorientation' or 'transformation' (Oladipo 2006:16). Since revelation is a historical process, Shona people, as well as all humanity, continue to have infinite horizons of experience of God as transcendent beings - they are continually engaging in the process of inculturation. Oladipo explains that 
conversion from one religion to another often seems superficial since the new faith often fails to touch certain psychic elements of the old spiritual awareness.

It has been shown that in the context of inculturation, African spirituality undergirded by the Bantu ethic that flows from ontology (essential cultural elements that include: unhu (personhood), umwe (togetherness), ushamwari (friendship), and hospitality) can be appreciated and appropriated against the backdrop of Christian values of the dignity of the human person of the imago Dei/Christi (image of God/Christ) as creation and baptismal derivatives, and the divine Great commandment of love. In the Christian Magna Carta of Galatians 3:28, the equality of believers is emphasised. In it all human boundaries are dissolved since through baptism we have all become brothers and sisters, children of the same Father. The Christian abba-adelphoi (Hebrew) relations concur with the Shona communio sanctorum corporate identity in which all are affirmed as hazvanzi nehazvanzi. We have seen that the Synod of Bishops in Africa (Rome 1994) acknowledged this in its postulate of the model of the church in Africa as family. Moreover, the African family spirit is further strengthened by the Christian orientation to pattern communal life on the Trinitarian koinonia.

In the womb and circle symbolism of Shona spirituality and holistic world view, it has been shown that women, far from being patriarchally circumscribed as passive receptors, play a central role in birthing and nurturing of children. As primary teachers of children - in the Shona hut with a central fire, woman can be portrayed as Lady Wisdom - the story teller (Chimhanda 2011b:108-109) and this image can be appropriated in the understanding of the Holy Spirit and giving a feminine face to the Trinitarian God and dynamic self-agency in the economy of salvation. In the context of Shona hospitality, this circle expands and contracts like the womb, in the process of affirming life. Consequently, the inculturation agenda must engage in serious consciousness-raising so that the oppressed and marginalized can consciously appropriate their God-given dignity and vocation. The starting point of this agenda is to conscientise Shona women on subtle and overt ways in which they collude with patriarchy and in so doing co-opt their own personhood (Chimhanda 2008). In the context of the Incarnation, women can be empowered by reading the Bible with women's eyes. In this project, women can draw energy and insights from Christ of the gospels who was an egalitarian teacher who used male and female images as in the parables in of the Kingdom of God, who in moral teaching, advocated symmetry of responsibility, e.g. as concerning adultery; and asked engaging questions to encouraged women to rise from the shackles of patriarchy.

The strength of the African communio sanctorum is the celebration of life from before birth to life after death that makes for a theanthropocosmic theology (Chimhanda 2011b:80). Here African spirituality and theology portray God as Pantokrator who, in the Incarnation showed commitment to earthly existence and in overcoming human limitedness, created catholic space in which human beings and all of creation receive the fullness of life. Of equal importance is the celebration of the rhythms of life that have enriched the African church so that it is known as the dancing church. Today in the upsurge of environmental crises, the world community has a lot to learn from the African holistic world view that has been shown above to be eco-friendly.

However, the African Bantu (Shona) communal identity and epistemology is sometimes criticized for compromising the unique individuality and autonomy of the human person especially when viewed against the Great Commandment that urges Christians to 
"love the Lord with your mind, and your neighbour as yourself" and appears to recognize the unique value of the individual. In the Shona perspective, violation of the dignity and rights of the human person is particularly true as regards patriarchal circumscription and marginalization of women and the girl child. Corporate identity gives Shona people group value and in practices of kuzvarira (pledged marriages), and wife substitution in cases of barrenness and kuripa ngozi (appeasement of vengeance spirits), the unique dignity and rights of women is trampled upon. The latter case exists in the appeasement of angry spirits for murder. A girl child from the family of the offender is given in marriage to the male kin of the deceased to produce a male child after which she may be freed. Other cases include roora which has lost its original bona fides (good will) intention when women are reduced to marketable goods. The latter, at its worst, is seen in the practice of kuroora guva (paying roora over the grave posthumously). The deceased woman is not given correct burial - is buried when she is a thing to be despised (decomposing state). The Zimbabwe government had to intervene in making it law to bury the deceased first and settle roora differences afterwards so as to give last respects to the deceased.

Another practice that has died out was the case of killing of twin babies. These were considered a bad omen. With the influence of Christianity and Westernisation, Shona people have learnt that all children are a gift from God.

However, it can be argued that the Shona have traditionally upheld the autonomy of the individual, especially as seen in the context of levirate marriage. Although women were marginalized as minors, the Shona proverb: nhaka ndeyemombe yemunhu inozvionera (only cattle can be inherited automatically; a person is free to accept or decline inheritance) acknowledges the autonomy of the person. The levirate ritual gives women a subtle way of declining levirate by giving the water of 'acceptance' to her son. This way she can stay in the marital group to look after her children.

In the Shona culture-Christianity dialogue, I have argued that both Shona culture and the Gospel have roots for the liberation of women and that in both texts, patriarchy shows historical development. The corollary of this is that culture is not sacrosanct and although the core message of the Gospel remains, with changing circumstances and needs, we can expand the view in a theology sensitive to the signs of the times.

\section{Conclusion}

It cannot be overemphasised that African Shona people are very religious and consequently show an emphasis on holistic religious experience and spirituality. The memory bank for African Bantu Shona theology and spirituality is found in oral tradition (myths, symbols of life, proverbs, songs and pithy sayings) and theology has to unpack this in a creative dialogue of culture and the Gospel. Thus the agenda to make African Bantu Shona people feel at home in their own faith and culture must take seriously essential cultural elements undergirded by communal ontology and epistemology in the God-human-cosmos mutual interdependence and connectedness. It has been shown that the African Bantu (Shona) theology and spirituality are environment-friendly. Consequently, such theology and spirituality can inform efforts to curb environmental crises and give direction towards sustainable development in looking at the past to inform the present and the future. However, it has also been shown that the strength of African Bantu (Shona) holistic worldview and spirituality can also be its weakness as in the case where, because of group value, the dignity and rights of the 
individual can be compromised. Over and above all, African Bantu (Shona) holistic worldview throws light on familial images of human relationality patterned on the Trinitarian koinonia; parenting and nurturing of the environment, and visioning the world as catholic space in which God is all in all.

\section{BIBLIOGRAPHY}

Aschwanden, H 1982. Symbols of life. Gweru: Mambo Press.

Ayisi, E 1972. An introduction to African culture. Nairobi: East African Publication.

Behemuka, J 1989. “The Hidden Treasure in African Traditional Religion”. In Jesus in African Traditional Religion.” Mugambi, JNK \& Magesa, L (eds.). Nairobi: Initiatives Publications, pp.1-16.

Bourdillon, M 1976. The Shona Peoples: An ethnography of the contemporary Shona with special reference to their religion. Gweru, Zimbabwe: Mambo Press.

Bourdillon, M 1993. Where are the Ancestors? Changing culture in Zimbabwe. Harare: University of Zimbabwe.

Chavhunduka, GL 1977. "Traditional medicine and Christian beliefs”. Christianity South of the Zambezi, vol. 3:131-146.

Chimhanda, FH 2008. "Raising consciousness regarding the dignity and vocation of women.” Studia Historiae Ecclesiaticae, vol. XXXIV:309-332.

Chimhanda, FH 2011a. Christ the ancestor, Shona Christianity and the roots for feminist liberative praxis. Saarbrücken: VDM.

Chimhanda, FH 2011b. An Incarnational narrative theology of Shona women of Zimbabwe. Saarbrücken: Lambert.

Daneel, ML 1970. The God of the Matopos Hills: An essay of the Mwari cult of Rhodesia. The Hague: Mouton.

Gaybba, B 1987. The spirit of love. London: Geoffrey Chapman.

Hick, J 1973. "Philosophy, of Religion”. Englewood Cliffs: Prentice Hall.

Kanyoro, MA 2002. Introducing feminist cultural hermeneutics: An African perspective. London: Sheffield Academic Press

Kaufman, G 1972. God the problem. Cambridge: Harvard University Press.

Kuckertz, H 1981. Ancestor religion in Southern Africa. Proceedings of a seminar on ancestor belief. Cacadu, Transkei: Lumko Missiological Institute.

Lane, D 1992. “The challenge of inculturation”. Living Light, no. 29:3-21.

Luzbetak, LJ 1988. The Church and cultures: New perspectives in Missiological anthropology. Maryknoll, New York: Orbis Books.

Mbiti, JS 1969. African Religions and Philosophy. London: Heinemann.

Mbuwayesango, DR 1997. "Childlessness and women-to-women relationships in Genesis and in African patriarchal society: Sarah and Hagar from a Zimbabwean women's perspective (Gen. 16:1-16; 21:8-21). Semeia, 79:27-36.

McGrath, AE 1997. Christian theology: An Introduction. Cambridge:

Blackwell Publishers. 
Manley, M 1995. Soil and Blood: Shona traditional Religion in late $20^{\text {th }}$ Century Zimbabwe. Pretoria: UNISA (unpublished MTh dissertation).

Mulago, V 1991. “Traditional African Religion and Christianity”, in African Traditional Religion in contemporary society. Jacob, K Olupona (ed.). New York: Paragon House, 119-134.

Nyamiti, C 1973. The Scope of African Theology. Uganda, Kampala: Gaba Publications.

Oladipo, CE 2006. The will to rise: Theological and African themes in African Christianity and the renewal of faith and identity. New York: Peter Lang.

Pato, LL 1997. "Being fully human: From the perspective of African culture”. Journal of Theology for Southern Africa, no. 97:62-67.

Pobee JS 1992. Skenosis: Christian faith in an African Context. Gweru: Mambo Press. .

Pope John XXIII 1965. Pacem in Terris - Peace on Earth. London: Catholic Truth Society.

Punt, J 1999. "Reading the Bible in Africa: Accounting for some trends". Scriptura, no. 71:313-329.

Rahner, K 1987. Foundations of Christian faith: An introduction to the idea of Christianity. New York: Crossroad.

Schoffeleers, JM 1978. Guardian of the land. Essays on Central African Territorial Cults. Gweru: Mambo Press.

Sheldrake, PF 2001. "Practising Catholic 'Place': The Eucharist”. Horizons, 28.2:163-182.

Thorpe, SA 1991. African traditional religions. Pretoria: UNISA.

Tillich, P 1968. Systematic theology for Southern Africa: Combined volume.

Digswell Place: James Nisbert \& Co Ltd. [paragraaf nie hanging nie]

Tutu, D 1995. An African Prayer Book. London: Hodder \& Stoughton.

Wanamaker, CA 1997. "Jesus the Ancestor: Reading the story of Jesus from African Christian context”. Scriptura, 63.3:281-298. 